\title{
I.UMIRUNC
}

\section{PEMANFAATAN TEPUNG DAUN PEGAGAN (Centella asiatica) SEBAGAI FEED ADDITIVE DALAM RANSUM TERHADAP KONSUMSI RANSUM DAN BERAT ORGAN FISIOLOGIS BROILER}

\author{
Yurni Sari Amir ${ }^{1}$, Muthia Dewi ${ }^{2}$, Prima Silvia Noor ${ }^{1}$, Toni Malvin ${ }^{2}$ dan \\ Egip Putra ${ }^{2}$ \\ ${ }^{1}$ Program Studi Paramedik Veteriner Politeknik Pertanian Negeri Payakumbuh \\ ${ }^{2}$ Program Studi Budi Daya Ternak Politeknik Pertanian Negeri Payakumbuh \\ Korespondensi: yurnisariamir@gmail.com
}

\author{
Diterima : :06 Agustus 2019 \\ Disetujui : 30 Agustus 2019 \\ Diterbitkan : 31 Agustus 2019
}

\begin{abstract}
ABSTRAK
Penelitian dengan memanfaatkan tepung daun pegagan sebagai feed additive dalam ransum broiler dilakukan untuk melihat pengaruhnya terhadap konsumsi ransum dan berat organ fisologis. Penelitian dilakukan di Laboratorium dan UPT Farm Politeknik Negeri Payakumbuh selama empat minggu, dengan menggunakan 100 ekor broiler yang dipelihara sejak DOC. Pakan yang diberikan berupa ransum basal dengan penambahan tepung daun pegagan. Rancangan yang digunakan adalah RAL dengan 4 perlakuan dan 5 ulangan, yaitu ransum basal $100 \%$ (A), ransum basal dengan penambahan $1,5 \%$ tepung daun pegagan (B), ransum basal dengan penambahan $3 \%$ tepung daun pegagan (C), ransum basal dengan penambahan tepung daun pegagan 4,5\% (D). Variabel yang diukur adalah konsumsi ransum, persentase bobot hati dan jantung. Hasil penelitian menunjukkan bahwa pencampuran tepung daun pegagan dalam ransum sebagai feed additive tidak memberikan pengaruh yang berbeda nyata $(\mathrm{P}>0,5)$ terhadap konsumsi ransum, bobot hati dan jantung broiler.
\end{abstract}

Kata Kunci: tepung daun pegagan, konsumsi ransum, bobot hati, jantung, broiler

\begin{abstract}
Research on the use of Centella asiatica leaf flour as a feed additive in broiler ration was conducted to see the effect on ration consumption and weight of physiological organs. The study was conducted at the Laboratory and UPT Farm of the State Polytechnic Payakumbuh for four weeks, using 100 broilers that have been maintained since DOC. The feed given is in the form of basal ration and the addition of gotu kola leaf flour. The design used was RAL 4 treatment with 5 replications, namely $100 \%$ ration (A), basal ration with the addition of $1.5 \%$ Centella asiatica leaf flour (B), basal ration with addition of $3 \%$ Centella asiatica leaf flour $(C)$, basal ration with the addition of Centella asiatica leaf flour $4.5 \%$ (D). The measured variables are the consumption of rations, the percentage of liver and heart weights. The results showed that mixing of gotu kola leaf flour in the ration as a feed additive did not significantly different effect $(P>0.5)$ on ration consumption, liver weight and heart of the broiler.
\end{abstract}

Keywords: gotu kola leaf flour, ration consumption, liver weight, heart, broiler 


\section{I.UMIBUNG}

\section{PENDAHULUAN}

Peternakan broiler merupakan salah satu bisnis yang cukup diminati oleh masyarakat karena perputaran modal yang cepat dan dagingnya disukai untuk dikonsumsi. Daging broiler lebih diminati masyarakat dibandingkan unggas lainnya karena dagingnya empuk, harganya yang cukup terjangkau dan memiliki kandungan gizi yang dibutuhkan tubuh. Penyediaan daging broiler bagi konsumsi masyarakat hendaknya memperhatikan aspek kehalalannya, sehat dan aman untuk dikonsumsi. Produk ini perlu diperhatikan dari awal pemeliharaan, bibit yang baik dan sehat, pakan yang terbebas dari tambahan antibiotik dan senyawa kimia sintetik serta proses pemotongan yang harus dijaga kebersihannya.

Penyediaan daging broiler yang sehat dan aman untuk dikonsumsi harus menjadi perhatian bagi para peternak broiler. Penggunaan antibiotik pada pakan atau air minum broiler secara terus menerus dan tidak berdasarkan aturan yang berlaku akan menimbulkan residu pada karkas broiler, apabila daging tersebut dikonsumsi akan membahayakan bagi kesehatan. Oleh karena itu diperlukan imbuhan pada pakan yang dapat memacu pertumbuhan broiler namun tidak meninggalkan residu bagi broiler tersebut sehingga dagingnya aman dan sehat untuk dikonsumsi manusia. Salah satu imbuhan alami yang dapat dimanfaatkan berasal dari tanaman pegagan.

Tanaman pegagan sudah cukup lama dikenal oleh masyarakat Indonesia. Pegagan ini mudah untuk dibudidayakan dan dipasarkan di pasar-pasar tradisional. Tanaman pegagan banyak terdapat di daerah persawahan atau ladang dengan kondisi tanah agak basah (Dewi, dkk, 2018). Salah satu manfaat pegagan adalah dapat digunakan sebagai sayuran dan untuk pengobatan, hal ini karena pada pegagan ditemukan adanya kandungan zat yang bermanfaat bagi kesehatan. Sutardi (2016) menyatakan bahwa tanaman pegagan memiliki kandungan vitamin, mineral dan bahan aktif yang berguna untuk menjaga kesehatan tubuh. Berdasarkan bahan aktif yang terkandung pada daun pegagan, maka dilakukan penelitian "Pemanfaatan Tepung Daun Pegagan (Centella asiatica) Sebagai Feed Additive Dalam Ransum Terhadap Konsumsi Ransum dan Berat Organ Fisiologis Broiler". 


\section{I.UMIRUNC}

\section{METODE PENELITIAN}

Penelitian ini menggunakan rancangan percobaan berupa rancangan acak lengkap (RAL), 4 perlakuan dan 5 ulangan. Perlakuan antara lain:

$$
\begin{aligned}
& A=0 \% \text { tepung pegagan } \\
& B=1,5 \% \text { tepung pegagan } \\
& C=3 \% \text { tepung pegagan } \\
& D=4,5 \% \text { tepung pegagan }
\end{aligned}
$$

Parameter yang diamati adalah konsumsi ransum, persentase bobot hati, dan jantung. Konsumsi ransum diperoleh dari selisih antara jumlah ransum yang diberikan dengan sisa ransum. Penimbangan ransum yang diberikan dan sisa ransum dilakukan setiap minggunya. Data bobot hati dan jantung diperoleh pada minggu keempat pemeliharaan dengan menimbang organ hati dan jantung. Penimbangan organ fisiologis dilakukan dengan menggunakan timbangan analitik yang dilakukan di laboratorium Peternakan. Persentase bobot hati dan jantung dihitung berdasarkan bobot masingmasing organ tersebut dibagi bobot hidup ayam dikalikan dengan 100\%. Data yang diperoleh dari peubah yang diamati diuji dengan analisis sidik ragam. Apabila terdapat perbedaan nyata $(\mathrm{P}<0.05)$ antar perlakuan akan dilanjutkan dengan uji jarak berganda Duncan`s New Multiple Range Test menurut Steel and Torrie (1993).

Penelitian ini berawal dengan penyediaan daun pegagan yang dijemur kering dan kemudian dihaluskan untuk dijadikan tepung. Tepung pegagan ini kemudian dicampurkan ke dalam ransum dengan persentase yang berbeda. Bahan pakan yang digunakan dalam penyusunan ransum basal terdiri dari dedak padi, jagung giling, bungkil kedele, bungkil kelapa, tepung ikan dan premix. Kandungan nutrisi ransum selama penelitian dapat dilihat pada Tabel 1 dan 2

Tabel 1. Kandungan nutrisi bahan pencampur ransum penelitian

\begin{tabular}{lcll}
\hline \multicolumn{1}{c}{ Bahan pakan } & PK $(\%)$ & LK $(\%)$ & SK $(\%)$ \\
\hline Tepung Pegagan* & 4,05 & 0,35 & 8,89 \\
Ransum Basal** & 15,05 & 7,19 & 27,77
\end{tabular}

Sumber: * Hasil penelitian Nur dkk (2017)

** Hasil analisis proksimat di Laboratorium Kimia Politeknik Pertanian

Negeri Payakumbuh (2018) 


\section{I.UMIRUNC}

Tabel 2. Kandungan nutrisi ransum perlakuan

\begin{tabular}{cccc}
\hline Perlakuan & PK (\%) & LK $(\%)$ & SK $(\%)$ \\
\hline A & 15,05 & 7,19 & 27,77 \\
B & 15,11 & 7,20 & 27,90 \\
C & 15,17 & 7,20 & 28,04 \\
D & 15,25 & 7,21 & 28,17 \\
\hline
\end{tabular}

Keterangan: Hasil perhitungan berdasarkan Tabel 1

\section{HASIL DAN PEMBAHASAN}

Pemanfaatan tepung daun pegagan sebagai feed additive di dalam ransum terhadap konsumsi ransum, persentase bobot hati dan jantung broiler dapat dilihat pengaruhnya pada Tabel 3 .

Tabel 3. Rataan konsumsi ransum, bobot hati dan jantung broiler.

\begin{tabular}{lccrc}
\hline \multirow{2}{*}{ Pengamatan } & \multicolumn{4}{c}{ Perlakuan } \\
\cline { 2 - 5 } & A & B & C & D \\
\hline Konsumsi Ransum (g/ekor/hr) & 84,59 & 84,29 & 85,86 & 87,93 \\
Bobot Hati (\%) & 2,36 & 2,54 & 2,86 & 2,47 \\
Bobot Jantung (\%) & 0,66 & 0,70 & 0,73 & 0,68 \\
\hline
\end{tabular}

\section{Konsumsi Ransum}

Berdasarkan hasil analisis keragaman pada Tabel 3 diketahui bahwa perlakuan pencampuran tepung daun pegagan dalam ransum memberikan pengaruh yang berbeda tidak nyata $(\mathrm{P}>0,05)$ terhadap konsumsi ransum broiler. Berbeda tidak nyatanya $(\mathrm{P}>0,05)$ perlakuan pencampuran tepung daun pegagan terhadap konsumsi ransum broiler dikarenakan kandungan nutrisi yang terkandung pada masing-masing ransum perlakuan tidak begitu berbeda (Tabel 2). Hal ini juga bisa disebabkan penggunaan level tepung daun pegagan pada interval yang rendah sehingga tidak menjadikan perbedaan nilai nutrisi yang terlalu berbeda setelah dicampurkan ke dalam ransum.

Pada Tabel 2 dapat dilihat bahwa kandungan serat kasar pada ransum cukup tinggi, berkisar $27,77 \%$ sampai dengan 28,17\%. Tingginya kandungan serat kasar ransum ini dikarenakan serat kasar ransum basal juga sudah tinggi yaitu 27,77\%. Kandungan serat kasar pada penelitian ini melebihi batas serat kasar dalam ransum 


\section{I.UMIRUNC}

broiler. Rizal (2006) menyatakan bahwa batasan serat kasar dalam ransum adalah antara 3-6\%. Serat kasar sebagian besar terdiri atas sellulosa dan lignin yang tidak mampu dicerna oleh saluran pencernaan unggas, dan biasanya ransum yang bahan pakannya memiliki kandungan serat kasar tinggi mempunyai nilai energi yang rendah, kecuali bahan pakan tersebut memiliki kandungan lemak yang tinggi (Wahju, 1997).

Rendahnya kandungan energi pada ransum berdampak pada konsumsi ransum. Suprijatna, Atmomarsono dan Kartasudjana (2005) menyatakan bahwa konsumsi ransum meningkat seiringan dengan menurunnya kandungan energi ransum. Ayam akan berhenti makan jika kebutuhan energinya sudah terpenuhi (Malvin, 2014). Bila dilihat pada Tabel 2, rata-rata konsumsi ransum broiler per ekor per hari adalah berkisar 84,29g sampai dengan 87,93g. Hasil penelitian Siregar, Nurmi dan Hasibuan (2017) didapatkan bahwa pemberian ekstrak pegagan memberikan pengaruh yang tidak nyata terhadap konsumsi ransum broiler dengan konsumsi berkisar 77,06g sampai 85,59g.

\section{Bobot Hati}

Berdasarkan hasil analisis keragaman pada Tabel 3 diketahui bahwa perlakuan pencampuran tepung daun pegagan dalam ransum memberikan pengaruh yang berbeda tidak nyata $(\mathrm{P}>0,05)$ terhadap persentase bobot hati broiler. Berbeda tidak nyatanya $(\mathrm{P}>0,05)$ perlakuan pencampuran tepung daun pegagan terhadap persentase bobot hati dikarenakan perbedaan level pencampuran tepung daun pegagan dalam ransum tidak terlalu signifikan, yaitu 1,5\% dalam ransum.

Nilai rataan persentase bobot hati broiler dari perlakuan berkisar antara 2,36\% sampai $2,86 \%$. Hal ini menandakan bahwa pencampuran tepung daun pegagan tidak menimbulkan dampak yang negatif terhadap organ hati broiler. Berdasarkan hasil pengamatan yang diperoleh, penggunaan daun pegagan dalam ransum tidak menyebabkan pembesaran dan pembengkakan pada hati, hal ini dikarenakan pada tepung daun pegagan tidak mengandung racun yang akan memberatkan kerja hati. Penggunaan tepung daun pegagan dalam ransum tidak menjadi toksik bagi tubuh, karena pada pegagan terdapat di dalamnya zat-zat yang berguna untuk kesehatan tubuh. Ramadhan (2015) menyatakan bahwa tanaman pegagan dapat dikonsumsi karena memiliki manfaat untuk pengobatan, salah satunya pegagan berfungsi sebagai antibakteri. Ditambahkan oleh Sutardi (2016) bahwa pada tanaman pegagan memiliki 


\section{I.UMIRUNC}

beberapa kandungan bahan aktif yang bermanfaat bagi kesehatan dan meningkatkan daya tahan tubuh,

\section{Bobot Jantung}

Berdasarkan hasil analisis keragaman pada Tabel 3 diketahui bahwa perlakuan pencampuran tepung daun pegagan dalam ransum memberikan pengaruh yang berbeda tidak nyata $(\mathrm{P}>0,05)$ terhadap persentase bobot jantung broiler. Rataan persentase bobot jantung dengan pemberian tepung daun pegagan berkisar antara $0,66 \%$ sampai dengan $0,73 \%$. Hal ini berarti bahwa pencampuran tepung daun pegagan sampai dengan $4,5 \%$ dalam ransum tidak membahayakan bagi pertumbuhan broiler, karena tidak adanya unsur toksik pada daun pegagan yang akan memberatkan kerja jantung. Menurut Frandson (1992), jantung sangat rentan pada zat antinutrisi dan racun, sehingga apabila racun terakumulasi pada otot jantung akan menyebabkan pembesaran jantung,

Daun pegagan juga bermanfaat untuk memperlancar peredaran darah, sehingga dengan pencampuran tepung daun pegagan dalam ransum dapat membantu kerja jantung untuk mengedarkan darah ke seluruh tubuh untuk proses metabolisme tubuh. Menurut Sutardi (2016) triterpenoid yang terkandung pada pegagan dapat memberikan efek menenangkan dan juga dapat memperlancar peredaran darah ke otak.

\section{KESIMPULAN}

Berdasarkan hasil dan pembahasan dapat disimpulkan bahwa pencampuran tepung pegagan dalam ransum broiler sampai dengan 4,5\% memberikan pengaruh yang berbeda tidak nyata terhadap konsumsi ransum dan berat organ fisologis.

\section{DAFTAR PUSTAKA}

Dewi, M., Malvin, T., Noor, P.S. and Amir, Y.S., 2018. Pengaruh Penambahan Pegagan (Centtela aciatica) Sebagai Pakan Additif Broiler Terhadap Persentase Karkas dan Lemak Abdomen. Prosiding, Politeknik Pertanian Negeri Payakumbuh.

Frandson. R.D. 1992. Anatomi dan Fisiologi. Gajah Mada Press. Yogyakarta.

Malvin, T., 2014. Perbandingan Pemberian Beberapa Level Mikrokapsul Minyak Ikan Dalam Ransum Terhadap Performa Broiler. J. Agrotropical, Vol 4. No 2. 


\section{I.UMIBUNG}

Nur. A.A.K., M. Devi dan L. Hidayati. 2017. Pengaruh penambahan pegagan (Centella asitica (L.) Urban) terhadap daya terima dan mutu kerupuk. Jurnal Aplikasi Teknologi Pangan. Vol. 6. No. 3.

Ramadhan. N.S., R. Rasyid dan Elmaris Sy. 2015. Daya hambat ekstrak daun pegagan (Centella asiatica) yang diambil di Batusangkar terhadap pertumbuhan kuman Vibrio cholera secara in vitro. Jurnal Kesehatan Andalas.

Rizal, Y. 2006. Ilmu Nutrisi Unggas. Andalas University Press. Padang

Siregar. R. A. S., A. Nurmi dan M. Hasibuan. 2017. Pemberian ekstrak pegagan (Centella asiatica) terhadap performans ayam broiler. Jurnal Peternakan. Vol. 01. No. 02.

Steel. R.G.D dan J.H.Torrie. 1993. Prinsip dan Prosedur Statistika Suatu Pendekatan Biometrik. PT. Gramedia Pustaka Utama. Jakarta.

Suprijatna. E., U. Atmomarsono dan R. Kartasudjana. 2005. Ilmu Dasar Ternak Unggas. Penebar Swadaya. Jakarta.

Sutardi. 2016. Kandungan bahan aktif tanaman pegagan dan khasiatnya untuk meningkatkan sistem imun tubuh. Jurnal Litbang Pertanian vol. 35. No. 3

Wahju, J. 1997. Ilmu Nutrisi Unggas. Gajah Mada University Press. Yogyakarta. 